\title{
Low C18 to C20 fatty acid elongase activity and limited conversion of stearidonic acid, 18:4(n-3), to eicosapentaenoic acid, 20:5(n-3), in a cell line from the turbot, Scophthalmus maximus
}

\author{
Cristina Ghioni*, Douglas R. Tocher, Michael V. Bell, James R. Dick, \\ John R. Sargent \\ Unit of Aquatic Biochemistry, Institute of Aquaculture, University of Stirling, \\ Stirling FK9 4LA, Scotland, UK.
}

\footnotetext{
*Corresponding author: Dr. Cristina Ghioni

Tel. +44 1786467993

Fax +44 1786472133

e-mail: cristina.ghioni@stir.ac.uk
}

Key words: Desaturase, elongase, octadecatetraenoic acid (stearidonic acid), deuterated fatty acids, cell culture, polyunsaturated fatty acids. 


\begin{abstract}
The TF cell line, derived from a carnivorous marine teleost, the turbot (Scophthalmus maximus), is known to have a reduced rate of polyunsaturated fatty acid (PUFA) biosynthesis. In order to establish the enzymic step responsible, the metabolic conversions of a range of PUFA including the key intermediates of n-3PUFA metabolism, stearidonic acid (18:4n-3) and its elongation product 20:4n-3, were studied in TF cells and compared with the AS cell line derived from Atlantic salmon (Salmo salar). Cells were cultured in the presence of unlabelled $(25 \mu \mathrm{M}),\left[\mathrm{U}^{14}{ }^{14} \mathrm{C}\right](1 \mu \mathrm{M} / 0.25 \mu \mathrm{Ci})$ or deuterated $(\mathrm{d} 5 ; 25 \mu \mathrm{M})$ fatty acids. The metabolism of stearidonic acid was qualitatively similar in both cell lines, predominantly elongation to $20: 4 n-3$ with subsequent desaturation to eicosapentaenoic acid (20:5n-3), but there were significant quantitative differences. The alternative techniques and mass concentrations of substrates used gave different amounts of overall conversion, but all the results were consistent with an apparent partial deficiency in $\mathrm{C}_{18}$ to $\mathrm{C}_{20}$ fatty acyl elongation in TF cells compared to AS cells. In contrast, $\Delta 5$ desaturation was apparently greater in TF cells than in AS cells. Only small amounts of docosahexaenoic acid (22:6n-3) were produced by either cell line, although there was significant production of $22: 5 n-3$, especially when $20: 4 n-3$ was supplemented to cultures. From the results obtained in this study it is concluded that there is an apparent partial deficiency of $\mathrm{C}_{18}$ to $\mathrm{C}_{20}$ fatty acyl elongation in the turbot cell line and that this, rather than lower fatty acyl $\Delta 5$ desaturation, may contribute to the reduced rate of conversion of $18: 3 n-3$ to $20: 5 n-3$ observed in the turbot compared with salmonid fish in vivo.
\end{abstract}




\section{Introduction}

Vertebtrate animals lack the $\Delta 12$ and $\Delta 15$ fatty acyl desaturase enzymes responsible for the production of $18: 2 n-6$ and $18: 3 n-3$ from $18: 1 n-9$ and so these essential fatty acids (EFA) are required in the diet and serve as the precursors for the longer-chain, more unsaturated polyunsaturated fatty acids (PUFA) characteristic of animal cells [1-4]. PUFA are essential components of biological membranes that have a role in the gross structural functions of the membrane, such as fluidity, and also have a considerable impact on the activity and function of membrane-associated proteins including receptors and enzymes [1-4]. PUFA themselves are precursors of a whole range of highly biologically active derivatives such as eicosanoids that are important in various forms of cell signalling [5-8]. Therefore, PUFA have important roles in both normal physiology and many pathological conditions. The EFA desaturation/elongation pathways in animals are still to be fully characterised as evidenced by the recent work suggesting that the production of $22: 6 n-3$ proceeded without the $\Delta 4$ desaturase activity classically thought to be responsible for introduction of the final double bond [9]. Studies of these pathways have been greatly facilitated by the use of cell lines [10].

The EFA requirements of freshwater and marine fish are qualitatively different. For example, in the freshwater rainbow trout (Oncorhynchus mykiss) 18:3n-3 alone can satisfy the EFA requirement, with 18:2n-6 only required for optimal growth [11]. However, in most marine species, including turbot (Scophthalmus maximus), the longer chain PUFA 20:5n-3 and 22:6n-3 are required [12]. This suggested a species difference in fatty acid desaturase/elongase activities and it was subsequently shown that this in vivo difference was also present in cultured cell lines [13]. Studies involving supplementation of turbot cells (TF) in culture, compared to both rainbow trout cells (RTG-2) and Atlantic salmon cells (AS), with various n3 and n-6 PUFA had shown that the deficiency in the desaturase/elongase pathway in turbot 
was either in the $\mathrm{C}_{18}$ to $\mathrm{C}_{20}$ elongase $\left(\mathrm{C}_{18-20}\right.$ elongase) or the fatty acyl $\Delta 5$ desaturase step $[13,14]$. Studies performed on turbot in vivo were also inconclusive but more consistent with a deficiency in the $\Delta 5$ desaturase activity as the fish appeared unable to produce specifically the $\Delta 5$ desaturation products $20: 4 n-6$ and 20:5n-3 [12,15]. In addition, results from in vivo studies with other marine fish species such as gilthead sea bream (Sparus aurata) and golden grey mullet (Liza aurata) were consistent with a deficiency in $\Delta 5$ desaturation $[16,17]$. Reduced

flux through desaturase/elongase pathways due to reduced desaturase activities have precedents in terrestrial carnivores such as cats in which $\Delta 6$ and $\Delta 5$ desaturase activities may both be severely limited [18-21]. It was hypothesised that this situation may be an evolutionary response to differences in diet. Therefore, whereas the natural diets of the generally more herbivorous/omnivorous freshwater fish, such as the well-studied salmonids, are relatively rich in $\mathrm{C}_{18}$ PUFA and do not contain much $\mathrm{C}_{20}$ or $\mathrm{C}_{22}$ PUFA, marine fish like the highly carnivorous turbot consume diets rich in 20:5n-3 and 22:6n-3 and so do not require to biosynthesise these PUFA [22,23].

As the situation in marine fish was unclear, we aimed to further define the enzymic location limiting the desaturase/elongase pathway in the turbot cell line. We report here the metabolism of various PUFA, including the key intermediates 18:4n-3 and 20:4n-3, in the TF and AS cell lines and that there was an apparent partial deficiency in $\mathrm{C}_{18-20}$ elongation and not $\Delta 5$ desaturation in TF cells.

\section{Materials and methods}

\section{Materials}

Unlabelled 18:4n-3 was purchased from Sigma Chemical Co. Ltd. (Poole, UK); its purity, checked by gas chromatography, was $91.5 \%$ with the remainder being $20: 5 n-3$ (4.5\%), 
unidentified 18:4 isomer (2.5\%), 20:3n-6 (1.1\%) and 20:2n-6 (0.4\%). Unlabelled 20:4n-3 (>95\%) was obtained from Cayman Chemical Company (Ann Arbor, MI, USA). $\left[1-{ }^{14} \mathrm{C}\right]$ fatty acids (18:1n-9, 18:2n-6, 20:3n-6, 18:3n-3 and 20:5n-3; all 50-55 $\mathrm{mCi} / \mathrm{mmol}$ and $>98 \%$ purity) were obtained from NEN Life Science Products Ltd. (Hounslow, U.K). Sodium $\left[{ }^{14} \mathrm{C}\right]$ bicarbonate $(\sim 50 \mathrm{mCi} / \mathrm{mmol})$ was purchased from ICN Biomedicals Ltd. (Thame, UK). Deuterated (d5-17,17,18,18,18)18:3n-3 ethyl ester was purchased from Cambridge Isotope Laboratories Inc., Andover, MA, USA. Thin layer chromatography (TLC) $(20 \mathrm{~cm} \mathrm{x} 20 \mathrm{~cm} \mathrm{x}$ $0.25 \mathrm{~mm})$ and high-performance TLC (HPTLC) $(10 \mathrm{~cm}$ x $10 \mathrm{~cm}$ x $0.25 \mathrm{~mm})$ plates, pre-coated with silica gel 60 were obtained from Merck, (Darmstadt, Germany). All solvents were of HPLC grade (Rathburn Chemicals, Walkerburn, Peebleshire, Scotland). Ecoscint A was purchased from National Diagnostic (Atlanta, Georgia). L-15 Medium Leibovitz, Hanks’ balanced salt solution (HBSS), fetal bovine serum (FBS), G/P/S (200 mM L-glutamate, 10000 $\mathrm{U}$ penicillin and $10 \mathrm{mg}$ streptomycin per $\mathrm{ml}$ of $0.9 \% \mathrm{NaCl}$ ), HEPES buffer, fatty acid-free bovine serum albumin (FAF-BSA) and trypsin/EDTA were obtained from Sigma Chemical Co. Ltd. (Poole, UK).

\section{Cell lines and medium}

The Atlantic salmon (Salmo salar) cell line (AS) [24] and the turbot (Scophthalmus maximus) cell line (TF) were as described previously [25]. Both were maintained at $22^{\circ} \mathrm{C}$ in Leibovitz L-15 medium supplemented with $10 \mathrm{mM}$ HEPES buffer, 2mM glutamine, antibiotics (50 IU/ml penicillin and $50 \mathrm{mg} / \mathrm{ml}$ streptomycin) and 10\% FBS.

\section{Preparation of fatty acid/bovine serum albumin (BSA) complexes}

Fatty acid/BSA complexes were prepared by dissolving $10 \mathrm{mg}$ of fatty acid in $100 \mu \mathrm{l}$ $0.1 \mathrm{M} \mathrm{KOH}$ and stirring for $10 \mathrm{~min}$ before adding $5 \mathrm{ml}$ of $50 \mathrm{mg} / \mathrm{ml} \mathrm{FAF-BSA}$ in HBSS and stirring the mixture for $45 \mathrm{~min}$ at $20^{\circ} \mathrm{C}$. The fatty acid/BSA complexes were filtered $(0.2 \mu \mathrm{m}$ - 
Flowpore D22) into sterile vials and the fatty acid concentration determined after extraction by addition of a known amount of 17:0 free fatty acid, transmethylation and analysis by gas chromatography (GC).

\section{Incubation of cell cultures with polyunsaturated fatty acids}

Cell cultures were routinely grown in $75 \mathrm{~cm}^{2}$ flasks in medium containing $10 \% \mathrm{FBS}$ and subcultured into medium containing $2 \%$ FBS $24 \mathrm{~h}$ prior to experimentation. All experiments were performed in triplicate with 6 flasks per sample for unlabelled fatty acids and one flask per sample for isotope experiments. All cultures used were subconfluent and growth continued during the experimental period. Unlabelled fatty acids were added at a concentration of 25 $\mu \mathrm{M}$ as BSA complexes in $70 \mu \mathrm{l}$ of medium with control flasks receiving the same quantity of BSA solution. $\left[1-{ }^{14} \mathrm{C}\right]$ fatty acids were added as BSA complexes $(0.25 \mu \mathrm{Ci} / \mathrm{flask})$; [U- $\left.{ }^{14} \mathrm{C}\right]$ 18:4n-3, obtained as methyl ester, was complexed with BSA and added to cells as described earlier. Because of the low yield that characterised the production of $\left[\mathrm{U}-{ }^{14} \mathrm{C}\right] 20: 4 n-3$ and of deuterated (d5) fatty acids in cell cultures and therefore the little mass available, these substrates were not added as BSA complexes, but directly as methyl esters in $50 \mu$ l of ethanol, to avoid the filtration step. [U- $\left.{ }^{14} \mathrm{C}\right] 20: 4 \mathrm{n}-3$ methyl ester was added at $0.13 \mu \mathrm{Ci}$ per flask. 18:4n-3 d5 and 20:4n-3 d5 methyl esters were added as 10\% and 5\% of total fatty acid respectively, after appropriate dilution with corresponding unlabelled methyl esters.

The details of the fatty acid substrates added to the cell cultures are summarised in Table 1. Preliminary experiments incubating AS cells with $25 \mu \mathrm{M}$ unlabelled $18: 4 \mathrm{n}-3$ as fatty acid salt/BSA complex, as methyl ester/BSA complex and as methyl ester in ethanol, showed no difference in the metabolism to $20: 4 n-3$ and 20:5n-3 after 6 days of culture, therefore these three chemical forms of substrate can be considered equivalent for the purpose of the present study. No accumulation of methyl esters was found in the lipid composition of cells incubated 
with methyl esters, compared to fatty acid salt/BSA complexes.

\section{Lipid extraction and analysis}

Medium was removed by aspiration, cells washed with $5 \mathrm{ml}$ phosphate buffered saline and then dissociated with $0.05 \%$ trypsin/ $0.02 \%$ EDTA solution. Cells were harvested in $3 \mathrm{ml}$ $\mathrm{HBSS}$, centrifuged at $300 \mathrm{~g}$ for $5 \mathrm{~min}$ at $4^{\circ} \mathrm{C}$, resuspended in $5 \mathrm{ml} \mathrm{HBSS}$ and $50 \mu \mathrm{l}$ taken for protein determination [26]. After centrifuging, cells were washed with $5 \mathrm{ml}$ HBSS containing $1 \%$ FAF-BSA, prior to extraction with $5 \mathrm{ml}$ ice-cold chloroform/methanol $(2: 1, \mathrm{v} / \mathrm{v})$ containing $0.01 \%$ butylated hydroxytoluene as antioxidant, according to Folch et al. [27]. Lipid was determined gravimetrically and resuspended in chloroform/methanol (as above) at a concentration of 10 or $100 \mathrm{mg} / \mathrm{ml}$ and stored at $-20^{\circ} \mathrm{C}$ under argon.

Separation and quantification of lipid classes was performed by single-dimension double-development HPTLC followed by scanning densitometry as described previously [28]. Fatty acid methyl esters (FAME) were prepared by acid-catalysed transmethylation, extracted and purified by HPTLC as described previously [29]. Analysis of FAME was performed by GC in a Fisons GC8000 gas chromatograph (Crawley, UK) equipped with a fused-silica capillary column (30m x $0.32 \mathrm{~mm}$ i.d., CP Wax $52 \mathrm{CB}$, Chrompack, UK) using hydrogen as carrier gas. Temperature programming was from 50 to $150^{\circ} \mathrm{C}$ at $35^{\circ} \mathrm{C} / \mathrm{min}$ and to $225^{\circ} \mathrm{C}$ at $2.5^{\circ} \mathrm{C} / \mathrm{min}$. Individual FAME were identified by comparison with known standards and published data $[30,31]$.

For radioisotope experiments, FAME were prepared as above and separated by argentation chromatography on TLC plates impregnated with $2 \mathrm{~g}$ silver nitrate in $20 \mathrm{ml}$ acetonitrile and activated at $110^{\circ} \mathrm{C}$ for $30 \mathrm{~min}$. Plates were developed with toluene/acetonitrile $(95: 5, \mathrm{v} / \mathrm{v})$ to separate PUFA [32] and autoradiography was performed using Kodak BioMax MR film for 6 days at room temperature. Bands corresponding to individual FAME, identified 
in comparison with known standards, were scraped from the plate and assayed for radioactivity by scintillation counting (TRI-CARB 2000CA, United Technologies Packard, Pangbourne, UK). Data were corrected for quench and counting efficiency determined. For $\left[\mathrm{U}-{ }^{14} \mathrm{C}\right] 18: 4 \mathrm{n}-3$ metabolism, the identity of radioactive fatty acids recovered from cell incubations was also confirmed by capillary radio-GC, by repeating the incubations with a higher concentration of substrate $(1 \mu \mathrm{Ci} /$ flask $)$.

Total lipid FAME of samples incubated with deuterated fatty acids were analysed by GC as above and the identity of deuterated fatty acids confirmed by GC mass-spectrometry (MS). Where the concentrations of deuterated fatty acids were too low to be determined in this way, FAME were derivatised to pentafluorobenzyl esters [33] and quantified by negative chemical ionisation GC-MS using 17:0 and 23:0 as internal standards. Briefly, fatty acid esters in hexane were separated on an MD800 mass spectrometer linked to a GC8000 GC (Fisons Instruments Ltd., Crawley, UK) equipped with a CP Wax 52CB fused silica capillary column (30 m x $0.32 \mathrm{~mm}$ i.d.; Chrompack, London, UK) and on-column injection using methane as carrier gas at a source pressure of $4 \times 10^{-4}$ torr. The source temperature was $150{ }^{\circ} \mathrm{C}$, the transfer line was maintained at $260{ }^{\circ} \mathrm{C}$ and the $\mathrm{GC}$ oven temperature programme was $50{ }^{\circ} \mathrm{C}$ to $190{ }^{\circ} \mathrm{C}$ at $40{ }^{\circ} \mathrm{C} / \mathrm{min}$, then to $240{ }^{\circ} \mathrm{C}$ at $1.5^{\circ} \mathrm{C}$ and held for $20 \mathrm{~min}$. Details of the MS analysis were as described previously by Pawlosky et al. [33].

Preparation of $\left[U_{-}{ }^{14} \mathrm{C}\right] 18: 4 n-3$ and $\left[U_{-}{ }^{14} \mathrm{C}\right] 20: 4 n-3$

$\left[\mathrm{U}-{ }^{14} \mathrm{C}\right] 18: 4 \mathrm{n}-3$ was obtained from cultures of the unicellular marine alga Isochrysis galbana (Parke) (S.M.B.A. strain No. 58 C.C.A.P. strain 927/1) grown in $300 \mathrm{ml}$ of f/2 media [34] containing $2.5 \mathrm{mCi}$ of sodium $\left[{ }^{14} \mathrm{C}\right]$ bicarbonate for 9 days at $20^{\circ} \mathrm{C}$ under constant light $\left(100 \mu \mathrm{E} \mathrm{s}^{-1}\right)$. Cells were harvested by centrifugation at $2500 \mathrm{~g}$ for $5 \mathrm{~min}$ and the algal pellet extracted with chloroform/propan-2-ol (2:1, v/v) [27]. Over $1 \mathrm{mCi}$ of radioactivity was 
recovered in the total lipid extract $(13 \mathrm{mg})$. The total lipid was applied to a TLC plate, chromatographed in diethyl ether, dried under vacuum and developed a second time in methyl acetate/propan-2-ol/ chloroform /methanol/ 0.25\% aqueous $\mathrm{KCl}$ (25:25:25:10:9, by vol.) [35]. After desiccation, mono- and di-galactosyldiacylglycerols (MGDG and DGDG) were detected under UV light after spraying with $0.1 \%$ 2',7'-dichlorofluorescein (DCF) in $97 \%$ methanol, the silica scraped and lipids transmethylated directly on the silica as above. FAME were extracted as described previously [29], quantified gravimetrically and radioactivity determined as described above. 25.1 $\mu \mathrm{Ci}$ were recovered in 0.63 mg FAME from MGDG and 11.2 $\mu \mathrm{Ci}$ were recovered in $0.29 \mathrm{mg}$ FAME from DGDG. FAME were separated by argentation TLC as above and the individual FAME bands identified after $1 \mathrm{~h}$ autoradiography. The silica containing 18:4n-3 was scraped from the plate, $5 \mathrm{ml} 2 \%$ aqueous $\mathrm{NaCl}$ added and the silica extracted 6 times with $10 \mathrm{ml}$ hexane/diethyl ether (1:1, v/v) and once with $20 \mathrm{ml}$ chloroform/ methanol $(2: 1, \mathrm{v} / \mathrm{v})$ to elute FAME. Pooled fractions were dried and radioactivity determined as above. A total of $5 \mu \mathrm{Ci}$ of $\left[\mathrm{U}_{-}{ }^{14} \mathrm{C}\right] 18: 4 \mathrm{n}-3$ was obtained, with a specific activity of approximately $12 \mathrm{mCi} / \mathrm{mmol}$. The identity of the 18:4n-3 was confirmed and its purity (>99\%) checked by radio-gas chromatography as described by Buzzi et al. [36].

$\left[\mathrm{U}-{ }^{14} \mathrm{C}\right] 20: 4 \mathrm{n}-3$ was biosynthesised by incubating AS cells $\left(10 \times 162 \mathrm{~cm}^{2}\right.$ flasks $)$ for 6 days with [U- $\left.{ }^{14} \mathrm{C}\right] 18: 4 \mathrm{n}-3(0.45 \mu \mathrm{Ci}$ per flask), added as a BSA complex in $50 \mu \mathrm{l}$ of medium. Cells were recovered and extracted as for fatty acid metabolism and $\left[\mathrm{U}-{ }^{14} \mathrm{C}\right] 20: 4 \mathrm{n}-3$ separated from transmethylated total lipid fatty acid by argentation TLC as for $18: 4 n-3$. Almost $1 \mu \mathrm{Ci}$ of $\left[\mathrm{U}-{ }^{14} \mathrm{C}\right] 20: 4 \mathrm{n}-3$ with a specific activity of approximately $12 \mathrm{mCi} / \mathrm{mmol}$ and $>99 \%$ purity, determined by radio-GC, was obtained.

Preparation of deuterated (d5)18:4n-3 and (d5)20:4n-3_

Deuterated (d5)18:4n-3 methyl ester was obtained from TF cells (6 x $75 \mathrm{~cm}^{2}$ flasks) 
incubated for 6 passages with (d5)18:3n-3 ethyl ester (25 $\mu \mathrm{M}$ added in $12 \mu$ l ethanol to each flask at each passage). Cell harvesting, lipid extraction and transmethylation of total lipid were performed as described above. The methyl ester of 18:4n-3 was separated by reverse-phase HPLC (C18 column, 25 x 1cm, 5 mm particle size; Altex Beckman, U.S.A) using acetonitrile (flow rate $1.5 \mathrm{ml} / \mathrm{min}$ ), and detected at $215 \mathrm{~nm}$. The identity and purity of fractions was determined by GC and the concentration of deuterated 18:4n-3 methyl ester was quantified using 17:0 as an internal standard. Unlabelled 18:4n-3 methyl ester was added to produce the concentration intended for use in experiments.

Deuterated (d5)20:4n-3 methyl ester was obtained from AS cells (6 x $75 \mathrm{~cm}^{2}$ flasks) incubated for 6 passages with (d5)18:4n-3 methyl ester. HPLC separation was performed as previously described, but as 20:4n-3 coeluted with 16:2n-9, the sample was rechromatographed using methanol/water $(97: 3, \mathrm{v} / \mathrm{v})$ at the same flow rate. Identity, purity and adjustment of concentration was performed as described above.

\section{Statistical analysis}

Results are presented as means $\pm \operatorname{SD}(n=3$ or 4$)$. The data were checked for homogeneity of the variances by the Bartlett test and, where necessary, the data were arc-sin transformed before further statistical analysis. Differences between mean values were analysed by the Student t-test or one-way analysis of variance (ANOVA), followed when pertinent by a multiple comparison test (Tukey). Differences were reported as statistically significant when $\mathrm{P}<0.05$ [37].

\section{Results}

Effects of 18:4n-3 and 20:4n-3 on cell growth, lipid content and composition

Supplementation of TF and AS cells with 18:4n-3 and 20:4n-3 at final concentrations of 
$25 \mu \mathrm{M}$ did non influence the proliferation rate of cells, nor their lipid content, as shown in Table 2. The only difference detected between the two cell lines was in the culture density, higher for TF than for AS cells as the latter are bigger cells. The ratio between the lipid and protein content of both cell lines was constant under all conditions ( $0.2 \mathrm{mg}$ lipid/ $\mathrm{mg}$ protein), indicating that no extra lipid deposition occurred in the cells due to supplementation with these fatty acids at the concentration used. Consistent with this, the lipid class compositions, which were very similar in TF and AS cells, were not significantly changed by supplementation with 18:4n-3 and 20:4n-3. The majority of lipids were polar lipids (72\%) with the neutral lipids being predominantly cholesterol (23\%). Phosphatidylcholine was the most abundant phospholipid (30\% of total lipid), followed by phosphatidylethanolamine (19\%), phosphatidylinositol (7.5\%) and phosphatidylserine (7\%).

\section{Effects of 18:4n-3 and 20:4n-3 on fatty acid compositions}

The fatty acid profiles of total lipids from TF and AS cells in control cultures (2\% FCS) and cultures supplemented with $25 \mu \mathrm{M}$ 18:4n-3 or 20:4n-3 are shown in Table 3. Total PUFA were only slightly increased in supplemented TF cells, whereas PUFA more than doubled in supplemented AS cells, compared to control cultures. PUFA of the n-3 series were increased in supplemented TF cells (up to 19-21\% from 8\%) and supplemented AS cells (up to 27-29\% from 6\%), compared to controls. Supplementation with 18:4n-3 increased18:4n-3 (from about zero to $8 \%$ in $\mathrm{TF}$ and $12 \%$ in $\mathrm{AS}$ ) and $20: 5 \mathrm{n}-3$ (from $0.5 \%$ to $3 \%$ in $\mathrm{TF}$ and from $0.8 \%$ to $5 \%$ in AS) in both cell lines, whereas 20:4n-3 was only increased (zero to 5\%) in AS cells. Similarly, supplementation with 20:4n-3 increased the percentages of 20:4n-3 (from approximately zero to $3 \%$ in TF and from zero to $12 \%$ in AS) and $20: 5 \mathrm{n}-3$ (from $0.5 \%$ to $6 \%$ in $\mathrm{TF}$ and from $0.8 \%$ to $7 \%$ in AS) in both cell lines. Supplementation with $20: 4 \mathrm{n}-3$ also increased 18:4n-3 (to 3\% in TF and 2.2\% in AS) in both cell lines. The percentage of 22:5n-3 
was increased in both cell lines, particularly when 20:4n-3 was supplemented, whereas 22:6n3 levels remained unaltered.

The increased percentages of n-3PUFA were balanced by decreased percentages of monoenes, predominantly 18:1n-9, in AS cells whereas in TF cells, although monoenes were decreased, the main balancing reduction was in n-9PUFA, predominantly 18:2n-9, which were reduced in supplemented cells (from 20\% to 12-13\%) (Table 3). PUFA of the n-6 series were only slightly decreased in 20:4n-3 supplemented cells in both lines. Saturated fatty acids were generally increased in supplemented cells, particularly TF cells, primarily due to increased 18:0.

\section{Metabolism of $\left[1-{ }^{14} \mathrm{C}\right] 18: 3 n-3,\left[U-{ }^{14} \mathrm{C}\right] 18: 4 n-3,\left[U-{ }^{14} \mathrm{C}\right] 20: 4 n-3$ and $\left[1-{ }^{14} \mathrm{C}\right] 20: 5 n-3$}

The metabolism of the n-3PUFA is presented as percentages of the total radioactivity recovered in individual PUFA (Table 4). With $\left[1-{ }^{14} \mathrm{C}\right] 18: 3 \mathrm{n}-3$, it is evident that, although the percentage of unmetabolised substrate is similar in both cells lines, the majority (64\%) was simply desaturated to $18: 4 \mathrm{n}-3$ in $\mathrm{TF}$ cells whereas almost $55 \%$ was both desaturated and further elongated in AS cells. [U- $\left.{ }^{14} \mathrm{C}\right] 18: 4 \mathrm{n}-3$ was mainly unaltered in TF cells (73\%), whereas over $81 \%$ was chain elongated in AS cells with $24 \%$ of radioactivity recovered in $20: 4 n-3$ and $48 \%$ in $20: 5 n-3$. In contrast, only $4 \%$ of radioactivity was recovered in $20: 4 n-3$ and $16 \%$ in 20:5n-3 in TF cells incubated with $\left[\mathrm{U}-{ }^{14} \mathrm{C}\right] 18: 4 n-3$. In contrast, more $\left[\mathrm{U}-{ }^{14} \mathrm{C}\right] 20: 4 \mathrm{n}-3$ was desaturated to $20: 5 n-3$ in TF cells (51\%) than in AS cells (34\%), where it mostly remained as 20:4n-3 (56\%). Some chain shortening of $\left[\mathrm{U}^{-14} \mathrm{C}\right] 20: 4 n-3$ to $18: 4 n-3$ was observed in both cell lines. The metabolism of $\left[1-{ }^{14} \mathrm{C}\right] 20: 5 \mathrm{n}-3$ was similar in TF and AS cells, most of it being retained as unmetabolised substrate. The main metabolite was its elongated product 22:5n-3 which accounted for about $9 \%$ of radioactivity recovered in both cell lines.

\section{Metabolism of $\left[1-{ }^{14} \mathrm{C}\right] 18: 1 n-9,\left[1-{ }^{14} \mathrm{C}\right] 18: 2 n-6$ and $\left[1-{ }^{14} \mathrm{C}\right] 20: 3 n-6$}


The results show that more $\left[1-{ }^{14} \mathrm{C}\right] 18: 1 \mathrm{n}-9$ was metabolised in $\mathrm{TF}$ cells $(35 \%$ unmetabolised) than in AS cells (77\% unmetabolised) and that in TF the substrate was mainly desaturated to $18: 2 \mathrm{n}-9$ (39\%) (Table 5). Similarly, more 18:2n-6 was unmetabolised in AS cells $(71 \%)$ than in TF cells $(50 \%)$, with $18: 3 n-6$ the predominant product in TF cells $(38 \%)$ while 20:3n-6 was the most abundant metabolite in AS cells (12\%). Approximately twice as much $\left[1-{ }^{14} \mathrm{C}\right] 20: 3 \mathrm{n}-6$ was desaturated to $20: 4 n-6$ and elongated to $22: 3 n-6$ in TF cells compared to AS cells.

\section{Metabolism of deuterated 18:3n-3, 18:4n-3 and 20:4n-3}

The results for the metabolism of deuterated fatty acids are presented in a similar way to the metabolism of ${ }^{14} \mathrm{C}$-labelled fatty acids, i.e. data are percentages (by weight) of total deuterated fatty acids recovered in total lipids (Table 6).

Approximately 5-fold more (d5)18:4n-3 was elongated to 20:4n-3 in AS cells compared to TF cells although comparable amounts of 20:5n-3 were found in both cell lines. In contrast, twice as much (d5) 20:4n-3 was recovered as the $\Delta 5$ desaturated product, 20:5n-3, in TF cells (42\%) compared to only $19 \%$ in AS cells.

Chain shortened products were generally more prominent in AS cells than TF cells (Table 6). For (d5)18:4n-3, twice as much deuterated 16:4n-3 was detected in AS cells compared to TF. The same fatty acid was also present in cells incubated with (d5)20:4n-3, again at higher levels in AS (11\%) than in TF (7\%), although comparable percentages of deuterated 18:4n-3 were detected.

\section{Individual metabolic steps in desaturation/elongation pathway}

A summary of the results obtained in the isotopic experiments, derived from the data contained in Tables 4-6, is presented in Table 7. The amounts of the products of each individual step in the desaturation/elongation pathway were summed taking into account all 
the fatty acids that are a result of that step, irrespective of subsequent conversions. The results obtained for each enzymatic process when incubating the cells with the fatty acid which is the direct substrate (i.e. 18:4n-3 for $\mathrm{C}_{18-20}$ elongase and 20:4n-3 for $\Delta 5$ desaturase) are of particular interest as they are an indication of the potential activity of each enzyme independent of the effects of enzymes preceding it in the pathway.

Table 7 shows $\mathrm{C}_{18-20}$ elongase products are always lower in TF cells than in AS cells for both n-6 and n-3 substrates, and this is particularly evident with the direct substrate, 18:4n-3, both radioactive (26\% in TF and $81 \%$ in AS) and deuterated (10\% in TF and $19 \%$ in AS). In contrast, $\Delta 5$ products are higher in TF cells compared to AS cells $(65 \%$ v. $40 \%, 71 \%$ v. $31 \%$ and $10 \%$ v. $6 \%$, respectively) when a direct substrate is given to the cells $\left(\left[\mathrm{U}-{ }^{14} \mathrm{C}\right] 20: 4 n-3\right.$, (d5)20:4n-3 and $\left[1-{ }^{14} \mathrm{C}\right] 20: 3 \mathrm{n}-6$, respectively). Similarly, $\Delta 6$ desaturase activity is higher in TF cells than in AS cells although the activity towards $\left[1-{ }^{14} \mathrm{C}\right] 18: 3 \mathrm{n}-3$ was comparable. $\mathrm{C}_{20-22}$

elongase products are also higher in TF cells incubated with $\left[1-{ }^{14} \mathrm{C}\right] 20: 3 n-6$, $\left[\mathrm{U}-{ }^{14} \mathrm{C}\right] 20: 4 \mathrm{n}-3$ or (d5)20:4n-3 compared to AS cells (13\% v. 8\%, 19\% v. $8 \%$ and $15 \%$ v. $5 \%$, respectively) or at least comparable, as shown in the incubations with $\left[1-{ }^{14} \mathrm{C}\right] 20: 5 \mathrm{n}-3$ (approximately $12 \%$ for both cell lines).

\section{Discussion}

The present study attempted to establish the enzyme responsible for reduced flux in the fatty acid desaturation/elongation pathway in a cell line, $\mathrm{TF}$, derived from turbot. In order to do this, the direct substrates for all the component enzymes in the pathway were required so that each step could be assayed and determined in isolation from the influence of preceding enzymes in the pathway. As isotopes for two crucial fatty substrates, 18:4n-3 (the direct substrate for $\mathrm{C}_{18-20}$ elongase) and 20:4n-3 (the direct substrate for $\Delta 5$ desaturase) were not 
available commercially they had to be synthesised before supplementation to TF and AS cells and analysis of the metabolic products. Therefore, the investigation focused on the metabolism of these two key intermediate fatty acids and in so doing suggested a likely biochemical cause for the lower rates of overall conversion in the marine fish, the turbot, when compared with the salmonid, the Atlantic salmon.

All the results, using unlabelled, $\left[1-{ }^{14} \mathrm{C}\right]-,\left[\mathrm{U}-{ }^{14} \mathrm{C}\right]-$ and $(\mathrm{d} 5)$-labelled fatty acids, are consistent with the fact that the TF cell line has a partial deficiency or reduced rate of $\mathrm{C}_{18-20}$ elongation, while $\Delta 5$ desaturase activity is apparently greater than in the AS cell line. In an earlier study on the TF cell line, "an apparent deficiency in the $\mathrm{C}_{18}$ to $\mathrm{C}_{20}$ elongase multienzyme complex" was hypothesised as the reason for the low conversion of $18: 3 \mathrm{n}-3$ to 20:5n-3 [13]. However, studies in vivo [12,15], together with the general belief that desaturase activities were more likely to be controlled and, therefore, the rate limiting steps in desaturation/elongation pathways [38] together with evidence that terrestrial carnivores appeared to lack, or express relatively low $\Delta 6$ and, possibly, $\Delta 5$ desaturases [18] led to the proposition that the $\Delta 5$ desaturase activity would be deficient in carnivorous marine fish in general, including turbot and sea bream (Sparus aurata L.) [16]. Only the use of isotopically labelled fatty acid intermediates could attempt to discriminate between the two hypotheses of reduced $\Delta 5$ desaturation or reduced $\mathrm{C}_{18-20}$ elongation.

The present results, suggesting that TF cells have a partial deficiency in $\mathrm{C}_{18-20}$ elongation would be consistent with the known EFA requirements of turbot. However, Maeda et al. [39] found that three out of six mammalian cell lines had lost $\Delta 6$ desaturase activity, $\Delta 5$ desaturase activity appeared to be absent in four cell lines and only one cell line expressed any desaturase activity beyond $\Delta 5$. There is also evidence for loss of stearoyl-CoA $\Delta 9$ desaturase in murine $\mathrm{T}$ lymphocytes in culture [40]. Therefore, loss or down -regulated activities in the desaturase/ 
elongase pathway may be a common feature of cell lines, and so it is prudent to be cautious in translating the results in cell culture to in vivo. In consequence, it is important to determine that this situation in TF cells is the one in vivo, and that TF cells are a model for the whole animal, via experiments with deuterated substrates similar to those performed by other authors in felines $[41,42]$ and humans $[43,44]$.

Cell culture studies have proved very useful in determining the potential effects of fatty acid supplementation on cellular fatty acid compositions as a more rapid and less expensive alternative to dietary trials with whole animals [13]. Therefore, the incubations with unlabelled 18:4n-3 and 20:4n-3 at $25 \mu \mathrm{M}$ showed the effects of these fatty acids on the fatty acid compositions of TF and AS cells. Previously, we established that a fatty acid concentration of $25 \mu \mathrm{M}$ in the medium alters the membrane phospholipid fatty acid composition of the cells without affecting the lipid class composition or precipitating the appearance of cytoplasmic lipid droplets [13]. The (d5) isotopes were also used at $25 \mu \mathrm{M}$ enabling the metabolism of the supplemented fatty acid to be determined under conditions known to affect fatty acid compositions. This is in contrast to the radiotracer studies where concentrations of fatty acid rarely exceed $1 \mu \mathrm{M}$, a concentration which has little impact on cellular fatty acid compositions. It is therefore noteworthy that the data obtained from all the experiments were generally consistent and qualitatively similar although there were quantitative differences between tracer experiments and those using a significant mass of fatty acid substrate. In the latter case, the effects of cellular fatty acid composition in altering enzyme substrate concentrations and inhibitory processes such as product inhibition are evident.

There are few data in the literature describing the metabolism via desaturation/elongation of either $18: 4 n-3$ or $20: 4 n-3$ by other cell lines. However, incubation of NIH-3T3 cells with approximately $70 \mu \mathrm{M}$ unlabelled 18:4n-3 resulted in the accumulation 
in phospholipids of primarily 20:5n-3 (15\%) and 20:4n-3 (11\%) followed by 18:4n-3 (10\%) and $22: 5 n-3(4 \%)$, whereas the percentage of $22: 6 n-3$ was only slightly increased [45]. This pattern was similar to AS cells except the percentages were higher in NIH-3T3 cells possibly due to a mass effect, as discussed above, as the level of 18:4n-3 supplemented to the $3 \mathrm{~T} 3$ cells was almost 3-fold greater. This also resulted in significant deposition of fatty acids, including $20: 4 n-3,18: 4 n-3$ and $20: 5 n-3$, in triacylglycerols which were increased from trace amounts to almost $16 \%$ of total cellular lipid [45], whereas there was no accumulation of fatty acid in neutral lipid and no accumulation of any neutral lipid class, including triacylglycerols, in the present study. In a separate feeding study, rats were fed a lipid-free diet supplemented with either 1\% 18:3n-3-ethyl ester or 1\% 18:4n-3-ethyl ester and the effects on fatty acid compositions of plasma and liver lipid fatty acid compositions determined [46]. The molar ratio of 20:5n-3 in most lipid fractions was approximately 2 -fold higher in the rats fed 18:4n-3, and $18: 4 n-3$ was found in the liver lipids in only very small amounts suggesting that it was rapidly metabolised to $20: 5 n-3$ and that $\Delta 6$ desaturase was the limiting step in the production of 20:5n-3 from 18:3n-3 [46].

Apparently higher levels of $\Delta 6$ desaturation were observed in the TF cell line compared to the AS cell line. Higher $\Delta 6$ desaturase activity in TF cells, compared to another cell line, RTG-2 from trout, had been reported previously [13], but is more interesting with the observation that TF also showed apparently higher $\Delta 5$ desaturase activity than AS cells. However, increased cellular levels of 18:2n-6 may inhibit $\Delta 6$ desaturation [47] and, as the level of 18:2n-6 is slightly higher in AS cells than in TF cells, this this may be a contributing factor. The use of sequential substrates clearly demonstrated how the previous enzyme in the desaturation/elongation pathway can affect the apparent activity of subsequent enzymes. For instance, with both $\left[1-{ }^{14} \mathrm{C}\right] 18: 3 n-3$ and $\left[\mathrm{U}-{ }^{14} \mathrm{C}\right] 18: 4 n-3$, the results could suggest that AS cells 
had higher $\Delta 5$ desaturase activity than TF cells but this is shown to be highly dependent on the preceding activities with reduced $\mathrm{C}_{18-20}$ elongase activity in TF cells.

In conclusion, the present results provide evidence that TF cells have a partial deficiency in $\mathrm{C}_{18-20}$ elongation which would be consistent with the known EFA requirements of turbot. However, it is important to determine that this situation is the one in vivo, and that TF cells are a model for the whole animal, so appropriate in vivo experiments perhaps similar to those performed in felines and humans are required [41-44].

\section{Acknowledgement}

Dr. C. Ghioni was supported by a grant from the European Union (FAIR GT97-0641).

\section{References}

[1] Stubbs, C.D. and Smith, A.D. (1984) Biochim. Biophys. Acta 779, 89-137.

[2] Spector, A.A. and Yorek, M.A. (1985) J. Lipid Res. 26, 1015-1035.

[3] Galli, C. (1992) In Essential Fatty Acids and Infant Nutrition (Ghisolfi, J. and Putet, G., eds), pp.3-10, J.Libby Eurotext Ltd., Montrouge, France.

[4] Slater, S.J., Kelly, M., Yeager, M.D., Larkin, J., Ho, C.J. and Stubbs, C.D. (1996) Lipids 31, S189-S192.

[5] Smith, W.L. (1989) Biochem. J. 259, 315-324.

[6] Fischer, S. (1989) Adv. Lipid Res. 23, 169-198.

[7] Kinsella, J.E., Lokesh, B., Broughton, S. and Whelan, J. (1990) Nutrition 6, 24-44.

[8] Lands, W.E.M. (1993) Annals. New York Acad. Sci. 676, 46-59.

[9] Sprecher, H., Luthria, D.L., Mohammed, B.S. and Baykousheva, S.P. (1995) J. Lipid Res. $36,2471-2477$. 
[10] Tocher, D. R., Leaver, M.J. and Hodgson, P.A. (1998) Prog. Lipid. Res. 37, 73-117.

[11] Castell, J.D., Sinnhuber, R.O., Wales, J.H. and Lee, D.J. (1972) J. Nutr. 102, 77-86.

[12] Owen, J.M., Adron, J.A., Middleton, C. and Cowey, C.B. (1975) Lipids 10, 528-531.

[13] Tocher, D.R., Carr, J. and Sargent, J.R. (1989) Comp. Biochem. Physiol. 94B, 367-374.

[14] Tocher, D.R. and Dick, J.R. (1990) Comp. Biochem. Physiol. 96B, 73-79.

[15] Bell, M.V., Henderson, R.J. and Sargent, J.R. (1985) Comp. Biochem. Physiol. 81B, 193198.

[16] Mourente, G. and Tocher, D.R. (1993) Biochim. Biophys. Acta 1212, 109-118.

[17] Mourente, G. and Tocher, D.R. (1994) Fish Physiol. Biochem. 12, 119-130.

[18] Rivers, J.P.W., Sinclair, A.J. and Crawford, M.A. (1975) Nature (London) 258, 171-173.

[19] Rivers, J.P.W., Hassam, A.G., Crawford, M.A. and Brambell, M.R. (1976) FEBS Lett. $1976,269-270$.

[20] Hassam, A.G., Rivers, J.P.W. and Crawford, M.A. (1977) Nutr. Metab. 21, 321-328.

[21] Sinclair, A.J., McLean, J.G. and Monger E.A. (1979) Lipids 14, 932-36.

[22] Bell, J.G., Ghioni, C. and Sargent, J.R. (1994) Aquaculture 128, 301-313.

[23] Sargent, J.R., Bell, M.V., Bell, J.G., Henderson, R.J. and Tocher, D.R. (1995) In Phospholipids: Characterization, Metabolism and Novel Biological Applications (Cevc, G. and Paltauf, F., eds), Ch.21, pp.248-259, AOCS Press, Champaign, Illinois.

[24] Nicholson, B.L. and Byrne, C. (1973) J. Fish Res. Bd. Can. 30: 913-916.

[25] Tocher, D.R., Sargent, J.R. and Frerichs, G.N.(1988) Fish Physiol. Biochem. 5, 519-227. 
[26] Lowry, O.H., Rosebrough, N.J., Farr, A.L. and Randall, R.J. (1951) J. Biol. Chem. 193, 265-275.

[27] Folch, J, Lee, M, Sloane-Stanley, G.H. (1957) J. Biol. Chem. 226, 497-509.

[28] Bell, J.G., Dick, J.R., McVicar, A.H., Sargent, J.R. and Thompson, K.D. (1993) Prostaglandins Leukotrienes Essent. Fatty Acids 49, 665-673.

[29] Tocher, D.R. and Harvie, D.G. (1988) Fish Physiol. Biochem. 5, 229-239.

[30] Ackman, R G. (1980) In Advances in Fish Science and Technology (Connell, J.J., ed.), pp. 86-103, Fishing New Books, Farnham, Surrey, UK.

[31] Bell, M.V., Simpson, C.M.F., Sargent, J.R. (1983) Lipids 18, 720-726.

[32] Wilson, R. and Sargent, J.R. (1992) J. Chromatogr. 623, 403-407.

[33] Pawlosky, J.R., Sprecher, H.W. and Salem, N. Jr. (1992) J. Lipid Res. 33, 1711-1717.

[34] Guillard, R.R.L and Ryther, J.H. (1962) Can. J. Microbiol. 8, 229-239.

[35] Vitiello, F. and Zanetta, J.-P. (1978) J. Chromatogr. 166, 637-640.

[36] Buzzi, M., Henderson, R.J. and Sargent, J.R. (1996) Biochim. Biophys. Acta 1299, 235244.

[37] Zar, J.H. (1984) in Biostatistical Analysis. Prentice Hall, Englewood Cliffs, New Jersey.

[38] Brenner, R.R. (1974) Mol. Cell. Biochem. 3, 41-52.

[39] Maeda, M., Doi, O. and Akamatsu, Y. (1978) Biochim. Biophys. Acta 530, 153-164.

[40] Buttke, T.M., Cleave, S.V., Steelman, L. and McCubrey, J.A. (1989) Proc. Natl. Acad. Sci. U.S.A. 86, 6133-6137.

[41] Tocher, D.R. and Sargent, J.R. (1990) J. Neurochem. 54, 2118-2124. 
[42] Pawlosky, J.R., Barnes, A. and Salem, N. Jr. (1994) J. Lipid Res. 35, 2032-2040.

[43] Rohwedder, W.K., Duval, S.M., Darhal, J.W. and Emken, E.A. (1990) Lipids 25, 401405.

[44] Salem, N. Jr., Wegher, B., Mena, P. and Uauy, R. (1996) Proc. Natl. Acad. Sci. USA 93, 49-54.

[45] Cantrill, R.C., Huang, Y.-S., Ells, G.W. and Horrobin, D.F. (1993) Lipids 28, 163-166.

[46] Yamazaki, K., Fujikawa, M., Hamazaki, T., Yano, S. and Shono, T. (1992) Biochim. Biophys. Acta 1123: 18-26.

[47] Rosenthal, M.D. (1987) Prog. Lipid Res. 26, 87-124. 
Table 1. Fatty acid substrates used in the experiments.

\begin{tabular}{|l|c|c|}
\hline Substrate & Molecular form & $\begin{array}{c}\text { Total concentration } \\
\text { added to cells }(\mu \mathrm{M})\end{array}$ \\
\hline $18: 4 n-3$ & FA/BSA & 25 \\
\hline $20: 4 n-3$ & FA/BSA & 25 \\
\hline$\left[1-{ }^{14} \mathrm{C}\right] 18: 3 n-3$ & FA/BSA & 0.33 \\
\hline$\left[U-{ }^{-14} \mathrm{C}\right] 18: 4 n-3$ & ME/BSA & 1.39 \\
\hline$\left[U-{ }^{14} \mathrm{C}\right] 20: 4 n-3$ & ME/ethanol & 0.72 \\
\hline$\left[1-{ }^{14} \mathrm{C}\right] 20: 5 n-3$ & FA/BSA & 0.33 \\
\hline$\left[1-{ }^{14} \mathrm{C}\right] 18: 1 n-9$ & FA/BSA & 0.33 \\
\hline$\left[1-{ }^{14} \mathrm{C}\right] 18: 2 n-6$ & FA/BSA & 0.33 \\
\hline$\left[1-{ }^{14} \mathrm{C}\right] 20: 3 n-6$ & FA/BSA & 0.33 \\
\hline$(d 5) 18: 4 n-3$ & ME/ethanol & 25 \\
\hline$(d 5) 20: 4 n-3$ & ME/ethanol & 25 \\
\hline
\end{tabular}

FA/BSA = fatty acid salt, bound to bovine serum albumin; methyl esters were added either complexed with BSA or in ethanol. 
Table 2. Lipid content of cells in control cultures and cultures supplemented with 18:4n-3 or 20:4n-3.

\begin{tabular}{|c|c|c|c|c|c|c|c|c|c|c|c|c|c|c|c|c|c|c|}
\hline \multirow[b]{3}{*}{ number of cells ( ${ }^{\star} 10$ millions) } & \multicolumn{9}{|c|}{ Turbot Fin } & \multicolumn{9}{|c|}{ Atlantic Salmon } \\
\hline & \multicolumn{3}{|c|}{ Control } & \multicolumn{3}{|c|}{$18: 4 n-3$} & \multicolumn{3}{|c|}{$20: 4 n-3$} & \multicolumn{3}{|c|}{ Control } & \multicolumn{3}{|c|}{$18: 4 n-3$} & \multicolumn{3}{|c|}{$20: 4 n-3$} \\
\hline & 3.5 & \pm & 0.8 & 3.9 & \pm & 1.0 & 3.1 & \pm & 0.4 & 2.6 & \pm & 0.2 & 2.0 & \pm & 0.7 & 2.4 & \pm & 0.3 \\
\hline mg lipid/mg protein & 0.2 & \pm & 0.0 & 0.2 & \pm & 0.0 & 0.2 & \pm & 0.0 & 0.2 & \pm & 0.0 & 0.2 & \pm & 0.0 & 0.2 & \pm & 0.0 \\
\hline mg lipid/million cells & 7.5 & \pm & 1.6 & 6.3 & \pm & 1.0 & 7.5 & \pm & 0.8 & 9.1 & \pm & 0.7 & 10.8 & \pm & 3.0 & 10.2 & \pm & 2.3 \\
\hline mg protein $/ 10$ million cells & 3.7 & \pm & 0.8 & 3.8 & \pm & 1.1 & 3.6 & \pm & 0.4 & 4.9 & \pm & 1.0 & 5.4 & \pm & 1.6 & 6.0 & \pm & 1.1 \\
\hline Results are means $\pm S D(n=3)$ & o dat & $\mathrm{La}$ & NIL11 & a ro & & or a & giver & 10 & II lin & re s & & $110 a$ & ly diff & & & & & \\
\hline
\end{tabular}


Table 3. Total lipid fatty acid compositions of cells in control cultures and cultures supplemented with $18: 4 n-3$ and $20: 4 n-3$.

\begin{tabular}{|c|c|c|c|c|c|c|c|c|c|c|c|c|c|c|c|c|c|c|c|c|c|c|c|c|c|c|}
\hline \multirow[b]{3}{*}{$14: 0$} & \multicolumn{13}{|c|}{ Turbot Fin } & \multicolumn{11}{|c|}{ Atlantic Salmon } & \multirow[b]{3}{*}{ a } & \multirow[b]{3}{*}{ * } \\
\hline & \multicolumn{3}{|c|}{ Control } & & \multicolumn{3}{|c|}{$18: 4 n-3$} & & \multicolumn{3}{|c|}{$20: 4 n-3$} & & & \multicolumn{4}{|c|}{ Control } & \multicolumn{4}{|c|}{$18: 4 n-3$} & \multicolumn{3}{|c|}{$20: 4 n-3$} & & \\
\hline & 0.7 & \pm & 0.1 & & 0.7 & \pm & 0.6 & & 1.6 & \pm & 0.3 & & & 0.8 & \pm & 0.1 & $a$ & 0.6 & \pm & 0.1 & $\mathrm{~b}$ & 0.7 & \pm & 0.1 & & \\
\hline $16: 0$ & 9.1 & \pm & 0.8 & b & 9.0 & \pm & 0.6 & b & 12.2 & \pm & 0.8 & a & ** & 9.4 & \pm & 0.4 & a & 8.0 & \pm & 0.2 & $\mathrm{~b}$ & 9.4 & \pm & 0.7 & a & * \\
\hline $16: 1 n-9$ & 4.7 & \pm & 0.4 & a & 3.5 & \pm & 0.6 & b & 3.8 & \pm & 0.2 & a & * & 3.3 & \pm & 0.2 & a & 2.1 & \pm & 0.2 & $\mathrm{~b}$ & 2.2 & \pm & 0.2 & c & *** \\
\hline $16: 1 n-7$ & 3.7 & \pm & 0.3 & & 3.1 & \pm & 0.6 & & 3.7 & \pm & 0.3 & & & 2.0 & \pm & 0.1 & a & 1.1 & \pm & 0.0 & $\mathrm{~b}$ & 1.2 & \pm & 0.1 & b & *** \\
\hline $18: 0$ & 10.9 & \pm & 1.3 & b & 15.6 & \pm & 2.1 & $a$ & 13.8 & \pm & 0.6 & $a b$ & * & 5.8 & \pm & 0.2 & c & 10.2 & \pm & 0.4 & $a$ & 7.6 & \pm & 0.8 & b & *** \\
\hline $18: 1 n-9$ & 12.9 & \pm & 1.2 & b & 13.4 & \pm & 0.9 & a & 11.0 & \pm & 0.6 & b & * & 39.9 & \pm & 1.0 & a & 22.6 & \pm & 1.0 & $\mathrm{~b}$ & 20.4 & \pm & 1.8 & b & 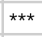 \\
\hline $18: 1 n-7$ & 4.2 & \pm & 0.5 & & 3.9 & \pm & 0.3 & & 3.4 & \pm & 0.3 & & & 3.9 & \pm & 0.1 & a & 2.9 & \pm & 0.1 & b & 2.8 & \pm & 0.3 & b & *** \\
\hline $18: 2 n-9$ & 16.0 & \pm & 2.0 & $a$ & 10.0 & \pm & 0.7 & b & 8.9 & \pm & 0.6 & b & *** & 1.3 & \pm & 0.2 & a & 0.6 & \pm & 0.0 & $b$ & 0.7 & \pm & 0.2 & b & ** \\
\hline $18: 2 n-6$ & 0.5 & \pm & 0.1 & a & 0.4 & \pm & 0.1 & a & 0.4 & \pm & 0.0 & $a b$ & * & 1.2 & \pm & 0.0 & a & 1.1 & \pm & 0.1 & $a b$ & 1.0 & \pm & 0.1 & b & * \\
\hline $18: 3 n-3$ & 0.2 & \pm & 0.2 & & 0.4 & \pm & 0.0 & & 0.2 & \pm & 0.2 & & & & - & & b & 0.4 & \pm & 0.1 & $a$ & & - & & b & 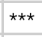 \\
\hline $18: 4 n-3$ & 0.2 & \pm & 0.2 & c & 7.6 & \pm & 1.2 & a & 2.6 & \pm & 0.3 & b & $\star \star \star \star ~$ & & - & & c & 11.5 & \pm & 0.8 & a & 2.2 & \pm & 0.3 & b & $\star \star \star ~$ \\
\hline $20: 2 n-6$ & 1.6 & \pm & 0.6 & a & 1.4 & \pm & 0.6 & a & 0.2 & \pm & 0.2 & b & * & 0.4 & \pm & 0.4 & & 0.0 & \pm & 0.0 & & 0.0 & \pm & 0.0 & & \\
\hline $20: 3 n-6$ & 0.9 & \pm & 0.1 & & 0.8 & \pm & 0.2 & & 0.5 & \pm & 0.2 & & & 1.2 & \pm & 0.1 & a & 1.1 & \pm & 0.2 & a & 0.3 & \pm & 0.4 & b & ** \\
\hline $20: 4 n-6$ & 2.4 & \pm & 0.3 & & 2.0 & \pm & 0.9 & & 2.4 & \pm & 0.1 & & & 2.9 & \pm & 0.1 & & 2.9 & \pm & 0.1 & & 2.6 & \pm & 0.3 & & \\
\hline $20: 4 n-3$ & & - & & b & 0.5 & \pm & 0.0 & b & 3.2 & \pm & 0.4 & a & 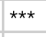 & & - & & c & 4.8 & \pm & 0.5 & b & 12.0 & \pm & 0.7 & a & *** \\
\hline $20: 5 n-3$ & 0.5 & \pm & 0.1 & c & 2.7 & \pm & 0.4 & b & 6.1 & \pm & 0.0 & a & *** & 0.8 & \pm & 0.1 & c & 4.6 & \pm & 0.4 & b & 7.1 & \pm & 1.2 & a & *** \\
\hline $22: 4 n-6$ & 0.5 & \pm & 0.1 & & 0.5 & \pm & 0.1 & & 0.4 & \pm & 0.0 & & & 0.4 & \pm & 0.0 & & 0.4 & \pm & 0.0 & & 0.2 & \pm & 0.2 & & \\
\hline $22: 4 n-3$ & 0.6 & \pm & 0.1 & & 0.7 & \pm & 0.2 & & 0.9 & \pm & 0.1 & & & 0.1 & \pm & 0.2 & c & 0.5 & \pm & 0.1 & $\mathrm{~b}$ & 1.4 & \pm & 0.1 & a & *** \\
\hline $22: 5 n-3$ & 1.1 & \pm & 0.1 & c & 2.0 & \pm & 0.2 & $\mathrm{~b}$ & 3.1 & \pm & 0.1 & a & *** & 1.6 & \pm & 0.0 & a & 2.0 & \pm & 0.2 & a & 2.9 & \pm & 0.4 & b & ** \\
\hline $22: 6 n-3$ & 4.9 & \pm & 0.3 & & 5.0 & \pm & 0.4 & & 4.7 & \pm & 0.3 & & & 3.8 & \pm & 0.4 & & 3.2 & \pm & 0.2 & & 3.1 & \pm & 0.5 & & \\
\hline Unknown & 4.9 & \pm & 0.4 & & 4.4 & \pm & 1.1 & & 4.6 & \pm & 0.9 & & & 4.1 & \pm & 2.2 & & 4.0 & \pm & 0.7 & & 5.9 & \pm & 1.2 & & \\
\hline Total saturates & 20.8 & \pm & 1.9 & $b$ & 25.3 & \pm & 1.2 & a & 27.7 & \pm & 1.1 & a & ** & 16.1 & \pm & 0.6 & b & 19.2 & \pm & 0.6 & a & 17.8 & \pm & 1.5 & $a b$ & * \\
\hline Total monoenes & 28.1 & \pm & 2.4 & a & 26.0 & \pm & 1.2 & $a b$ & 23.5 & \pm & 1.3 & b & * & 51.6 & \pm & 1.2 & a & 30.9 & \pm & 1.1 & b & 27.9 & \pm & 2.6 & b & *** \\
\hline Total PUFA & 34.5 & \pm & 1.8 & & 37.7 & \pm & 1.6 & & 37.6 & \pm & 1.0 & & & 16.3 & \pm & 0.5 & b & 36.3 & \pm & 1.1 & a & 36.1 & \pm & 3.2 & a & $\star \star \star ~$ \\
\hline Total n-9 PUFA & 19.7 & \pm & 2.3 & a & 13.2 & \pm & 0.6 & b & 12.1 & \pm & 0.7 & b & ** & 3.1 & \pm & 0.2 & & 3.1 & \pm & 0.4 & & 2.8 & \pm & 0.4 & & \\
\hline Total n-6 PUFA & 6.1 & \pm & 0.6 & a & 5.5 & \pm & 0.9 & $a b$ & 4.2 & \pm & 0.3 & b & * & 6.2 & \pm & 0.5 & a & 5.5 & \pm & 0.1 & a & 4.1 & \pm & 0.4 & b & $\star \star$ \\
\hline Total n-3 PUFA & 7.6 & \pm & 0.3 & b & 18.9 & \pm & 2.1 & a & 20.7 & \pm & 0.3 & a & *** & 6.3 & \pm & 0.5 & b & 27.1 & \pm & 0.8 & a & 28.6 & \pm & 2.6 & a & *** \\
\hline Total DMA & 2.6 & \pm & 1.9 & & 3.2 & \pm & 0.3 & & 2.3 & \pm & 0.3 & & & 5.1 & \pm & 0.5 & & 4.3 & \pm & 0.5 & & 4.5 & \pm & 0.7 & & \\
\hline
\end{tabular}

Results are percentages of weight (means $\pm S D ; n=3$ ). Total saturates include 15:0 and 17:0; total monoenes include 17:1 $n-9$, 18:1n-5, 20:1n-9 and 22:1n-9; total n-9 PUFA include 16:2n-9, 17:2n-9, 20:2n-9, 20:3n-9 and 22:2n-9.

Asterisks denote significance by ANOVA, ${ }^{* \star}, p<0.001 ;{ }^{*}, p<0.01 ; *, p<0.05$; values in the same row for the same cell line with different superscript letters are significantly different (Tukey's multiple comparison test) 
Table 4. Metabolism of $[1-14 \mathrm{C}] 18: 3 n-3,\left[\mathrm{U}-{ }^{14} \mathrm{C}\right] 18: 4 n-3,\left[\mathrm{U}-{ }^{14} \mathrm{C}\right] 20: 4 n-3$ and $\left[1-{ }^{14} \mathrm{C}\right] 20: 5 n-3$ in cell cultures.

\begin{tabular}{|c|c|c|c|c|c|c|c|c|c|c|c|c|c|c|c|c|c|c|c|c|c|c|c|c|c|c|c|c|}
\hline \multirow[b]{3}{*}{$18: 3$} & \multicolumn{6}{|c|}{$\left[1-{ }^{-14} \mathrm{C}\right] 18: 3 n-3$} & & \multicolumn{6}{|c|}{$\left[\mathrm{U}-{ }^{14} \mathrm{C}\right] 18: 4 \mathrm{n}-3$} & & \multicolumn{6}{|c|}{$\left[\mathrm{U}-{ }^{14} \mathrm{C}\right] 20: 4 n-3$} & & \multicolumn{6}{|c|}{$\left[1-{ }^{14} \mathrm{C}\right] 20: 5 n-3$} & \\
\hline & \multicolumn{3}{|c|}{ TF } & \multicolumn{3}{|c|}{$\mathrm{AS}$} & & \multicolumn{3}{|c|}{ TF } & \multicolumn{3}{|c|}{ AS } & & \multicolumn{3}{|c|}{ TF } & \multicolumn{3}{|c|}{$\mathrm{AS}$} & & \multicolumn{3}{|c|}{ TF } & \multicolumn{3}{|c|}{$\mathrm{AS}$} & \\
\hline & 17.3 & \pm & 0.7 & 18.3 & \pm & 1.3 & & & - & & & - & & & & - & & & - & & & & - & & & - & & \\
\hline $18: 4$ & 64.2 & \pm & 1.0 & 21.4 & \pm & 0.8 & ** & 74.1 & \pm & 0.8 & 18.8 & \pm & 1.0 & *夫 & 3.9 & \pm & 0.6 & 2.2 & \pm & 0.9 & & & - & & & - & & \\
\hline $20: 3$ & 0.9 & \pm & 0.1 & 5.6 & \pm & 0.1 & ** & & - & & & - & & & & - & & & - & & & & - & & & - & & \\
\hline $20: 4$ & 4.5 & \pm & 0.2 & 14.9 & \pm & 0.7 & ** & 4.4 & \pm & 0.0 & 23.6 & \pm & 1.3 & $\star \star$ & 26.9 & \pm & 0.2 & 56.2 & \pm & 0.5 & ** & & - & & & - & & \\
\hline $20: 5$ & 9.9 & \pm & 0.2 & 34.8 & \pm & 2.1 & ** & 16.4 & \pm & 0.5 & 48.4 & \pm & 1.7 & ** & 51.4 & \pm & 0.7 & 33.8 & \pm & 0.4 & ** & 87.2 & \pm & 1.0 & 87.8 & \pm & 2.4 & \\
\hline $22: 4$ & 1.9 & \pm & 0.1 & 1.0 & \pm & 0.1 & ** & 0.8 & \pm & 0.1 & 1.2 & \pm & 0.3 & & 6.9 & \pm & 0.1 & 2.8 & \pm & 0.1 & $\star \star$ & & - & & & - & & \\
\hline $22: 5$ & 1.0 & \pm & 0.1 & 3.7 & \pm & 0.6 & ** & 1.6 & \pm & 0.3 & 4.5 & \pm & 0.5 & ** & 6.7 & \pm & 0.1 & 3.2 & \pm & 0.3 & ** & 8.1 & \pm & 0.9 & 9.8 & \pm & 2.8 & \\
\hline $22: 6$ & 0.2 & \pm & 0.0 & 0.2 & \pm & 0.1 & & & - & & 1.7 & \pm & 0.3 & $\star \star$ & 2.2 & \pm & 0.6 & 0.7 & \pm & 0.2 & * & 4.2 & \pm & 0.6 & 1.4 & \pm & 0.4 & ** \\
\hline $24: 4$ & & - & & & - & & & 1.2 & \pm & 0.3 & & - & & ** & & - & & & - & & & & - & & & - & & \\
\hline $24: 5$ & & - & & & - & & & 1.5 & \pm & 0.4 & 1.8 & \pm & 0.2 & & 2.0 & \pm & 0.6 & 1.1 & \pm & 0.2 & & 0.5 & \pm & 0.1 & 0.9 & \pm & 0.1 & ** \\
\hline
\end{tabular}

Results are expressed as percentages of total radioactivity recovered and are means \pm SD $(n=3)$. TF, Turbot Fin Cells; AS, Atlantic Salmon Cells; ${ }^{\star \star}$, $p$ t-test $<0.01$; ${ }^{\star}$, p t-test $<0.05$; -, not detecte 
Table 5. Metabolism of $\left[1^{-14} \mathrm{C}\right] 18: 1 \mathrm{n}-9,\left[1^{-14} \mathrm{C}\right] 18: 2 \mathrm{n}-6$ and $\left[1-{ }^{14} \mathrm{C}\right] 20: 3 \mathrm{n}-6$ in cell cultures.

\begin{tabular}{|c|c|c|c|c|c|c|c|c|c|c|c|c|c|c|c|c|c|c|c|c|c|c|}
\hline \multirow[b]{3}{*}{ Sats } & \multicolumn{6}{|c|}{$\left[1-{ }^{14} \mathrm{C}\right] 18: 1 \mathrm{n}-9$} & & & \multicolumn{6}{|c|}{$\left[1-{ }^{14} \mathrm{C}\right] 18: 2 n-6$} & & \multicolumn{6}{|c|}{$\left[1-{ }^{14} \mathrm{C}\right] 20: 3 n-6$} & \\
\hline & \multicolumn{3}{|c|}{ TF } & \multicolumn{3}{|c|}{ AS } & \multirow[b]{2}{*}{ ** } & & \multicolumn{3}{|c|}{ TF } & \multicolumn{3}{|c|}{$\mathrm{AS}$} & & \multicolumn{3}{|c|}{ TF } & \multicolumn{3}{|c|}{ AS } & \\
\hline & 11.1 & \pm & 0.2 & 13.8 & \pm & 0.9 & & & & & & & & & & & & & & & & \\
\hline 18:1 & 34.8 & \pm & 1.0 & 77.0 & \pm & 2.0 & ** & 18:2 & 49.9 & \pm & 0.8 & 70.9 & \pm & 2.5 & ** & & & & & & & \\
\hline $18: 2$ & 38.8 & \pm & 0.9 & 2.7 & \pm & 0.8 & ** & 18:3 & 38.3 & \pm & 1.0 & 7.6 & \pm & 2.2 & ** & & & & & & & \\
\hline 20:1 & 2.6 & \pm & 0.3 & 2.1 & \pm & 1.5 & & $20: 2$ & 1.8 & \pm & 0.5 & 5.8 & \pm & 1.0 & ** & & & & & & & \\
\hline $20: 2$ & 3.7 & \pm & 0.7 & 1.1 & \pm & 0.2 & ** & $20: 3$ & 5.3 & \pm & 0.3 & 12.1 & \pm & 0.9 & ** & 77.5 & \pm & 0.8 & 87.4 & \pm & 0.5 & ** \\
\hline $20: 3$ & 5.8 & \pm & 0.4 & 2.7 & \pm & 0.7 & *夫 & $20: 4$ & 1.4 & \pm & 0.1 & 1.4 & \pm & 0.2 & & 9.6 & \pm & 0.3 & 4.2 & \pm & 0.2 & *夫 \\
\hline $22: 2$ & 1.7 & \pm & 0.1 & & - & & *夫 & $22: 3$ & 1.0 & \pm & 0.0 & 0.7 & \pm & 0.1 & 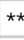 & 11.8 & \pm & 0.7 & 6.0 & \pm & 0.2 & ** \\
\hline $22: 3$ & 1.5 & \pm & 0.3 & 0.7 & \pm & 0.1 & $\star \star \star$ & $22: 4$ & 2.3 & \pm & 0.1 & 1.5 & \pm & 0.3 & * & 0.8 & \pm & 0.4 & 1.3 & \pm & 0.6 & \\
\hline & & & & & & & & $24: 3$ & & & & & & & & 0.5 & \pm & 0.1 & 1.1 & \pm & 0.3 & * \\
\hline
\end{tabular}

Results are expressed as percentages of total radioactivity recovered and are means \pm SD $(n=3)$. TF, Turbot Fin Cells; AS, Atlantic Salmon Cells; ${ }^{\star \star}, \mathrm{p}$ t-test $<0.01$; ${ }^{*}$, p t-test $<0.05$; -, not detecte 
Table 6. Metabolism of deuterated $18: 4 n-3$ and $20: 4 n-3$ in cell cultures.

\begin{tabular}{|c|c|c|c|c|c|c|c|c|c|c|c|c|c|c|c|c|c|}
\hline \multirow{3}{*}{$\begin{array}{r}\text { Fatty } \\
\text { Acids } \\
\text { Applied (pmoles) }\end{array}$} & \multicolumn{8}{|c|}{$(d 5) 18: 4 n-3$} & \multicolumn{8}{|c|}{$(d 5) 20: 4 n-3$} & \\
\hline & \multicolumn{4}{|c|}{$\mathrm{TF}$} & \multicolumn{4}{|c|}{ AS } & \multicolumn{4}{|c|}{ TF } & \multicolumn{4}{|c|}{ AS } & \\
\hline & & & & & & & & & & & & & & & & & \\
\hline Unlabelled (UI) & \multicolumn{3}{|c|}{337500} & & \multicolumn{3}{|c|}{337500} & & \multicolumn{3}{|c|}{356250} & & \multicolumn{3}{|c|}{356250} & & \\
\hline Deuterated (d5) & \multicolumn{3}{|c|}{37500} & & \multicolumn{3}{|c|}{37500} & & \multicolumn{3}{|c|}{18750} & & \multicolumn{3}{|c|}{18750} & & \\
\hline Mass $(\mathrm{Ul}+\mathrm{d} 5)$ & \multicolumn{3}{|c|}{375000} & & \multicolumn{3}{|c|}{375000} & & \multicolumn{3}{|c|}{375000} & & \multicolumn{3}{|c|}{375000} & & \\
\hline \multicolumn{18}{|l|}{ Recovered pmols (mol\%) } \\
\hline $16: 4$ & 245 & \pm & 78 & $(6.7)$ & 522 & \pm & 2 & $(12.7)$ & 177 & \pm & 48 & $(6.1)$ & 259 & \pm & 91 & $(9.7)$ & \\
\hline $18: 4$ & 2947 & \pm & 489 & $(82.7$ & 2726 & \pm & 4 & $(68.1)$ & 566 & \pm & 142 & (19.7) & 463 & \pm & 123 & $(17.4)$ & \\
\hline $20: 4$ & 73 & \pm & 21 & $(2.0)$ & 411 & \pm & 1 & $(10.1)^{\star * *}$ & 510 & \pm & 76 & (17.8) & 1289 & \pm & 360 & (48.1) & * \\
\hline $20: 5$ & 280 & \pm & 127 & $(7.5)$ & 335 & \pm & 2 & $(8.2)$ & 1255 & \pm & 176 & $(44.2)$ & 561 & \pm & 171 & (20.9) & ** \\
\hline $22: 4$ & 8 & \pm & 2 & $(0.2)$ & 9 & \pm & 0 & $(0.2)$ & 89 & \pm & 14 & $(3.1)$ & 51 & \pm & 14 & (1.9) & * \\
\hline $22: 5$ & 18 & \pm & 9 & $(0.5)$ & 21 & \pm & 0 & $(0.5)$ & 232 & \pm & 31 & $(8.1)$ & 43 & \pm & 11 & $(1.6)$ & ** \\
\hline $22: 6$ & 10 & \pm & 1 & $(0.3)$ & 8 & \pm & 0 & $(0.2)$ & 28 & \pm & 4 & $(1.0)$ & 11 & \pm & 4 & $(0.4)$ & ** \\
\hline Total & 3582 & \pm & 717 & & 4033 & \pm & 803 & $(6.7)$ & 2856 & \pm & 234 & & 2677 & \pm & 753 & & \\
\hline \multicolumn{18}{|l|}{ Total mass recovered/ } \\
\hline mass applied (\%) & 1.0 & \pm & 0.2 & & 1.1 & \pm & 0.2 & & 0.8 & \pm & 0.1 & & 0.7 & \pm & 0.2 & & \\
\hline
\end{tabular}

Results(mean \pm S.D.; $n=3$ ) are expressed as pmols of fatty acids and/or mole\%. TF, Turbot Fin Cells; AS, Atlantic Salmon Cells; **, P t-test $<0.01 ;{ }^{*}$, P t-test $<0.05$ 
Table 7. Products of desaturase and elongase activities in cell cultures incubated with various radioactive and deuterated substrates.

\begin{tabular}{|c|c|c|c|c|}
\hline & 1st Enzyme & Units & TF & AS \\
\hline$\left[1-{ }^{14} \mathrm{C}\right] 18: 1 \mathrm{n}-9$ & $\Delta 6$ desaturase & Radioactivity \% & $51.5 \pm 0.8$ & $7.1 \pm 0.6^{\star \star}$ \\
\hline$\left[1-{ }^{14} \mathrm{C}\right] 18: 2 \mathrm{n}-6$ & $\Delta 6$ desaturase & Radioactivity \% & $48.3 \pm 1.2$ & $23.4 \pm 3.3^{* *}$ \\
\hline$\left[1-{ }^{14} \mathrm{C}\right] 18: 3 \mathrm{n}-3$ & $\Delta 6$ desaturase & Radioactivity \% & $81.9 \pm 0.7$ & $76.0 \pm 1.4^{*}$ \\
\hline$\left[\mathrm{U}-{ }^{14} \mathrm{C}\right] 18: 4 \mathrm{n}-3$ & $\mathrm{C}_{18-20}$ elongase & Radioactivity \% & $25.9 \pm 0.8$ & $81.2 \pm 1.0^{* *}$ \\
\hline d5 $18: 4 n-3$ & $\mathrm{C}_{18-20}$ elongase & mole $\%$ & $10.6 \pm 2.7$ & $19.2 \pm 3.5^{*}$ \\
\hline$\left[\mathrm{U}-{ }^{14} \mathrm{C}\right] 20: 4 n-3$ & $\Delta 5$ desaturase & Radioactivity \% & $62.3 \pm 0.7$ & $38.8 \pm 0.3^{* *}$ \\
\hline d5 $20: 4 n-3$ & $\Delta 5$ desaturase & mole $\%$ & $53.2 \pm 6.6$ & $22.9 \pm 0.7^{* *}$ \\
\hline$\left[1-{ }^{14} \mathrm{C}\right] 20: 3 \mathrm{n}-6$ & $\Delta 5$ desaturase & Radioactivity \% & $10.3 \pm 0.4$ & $5.5 \pm 0.6 * \star$ \\
\hline$\left[1-{ }^{14} \mathrm{C}\right] 20: 5 n-3$ & $\mathrm{C}_{20-22}$ elongase & Radioactivity \% & $12.8 \pm 1.0$ & $12.2 \pm 2.4$ \\
\hline
\end{tabular}

Results are \% of weight of total radioactivity recovered (means $\pm S D ; n=3$ ). TF, Turbot Fin Cells; AS, Atlantic Salmon Cells.

For deuterated and [ $-14 \mathrm{C}$ ] labelled fatty acid substrates the percentages were calculated excluding chain shortened products to enable comparison with [1-14C] labelled substrate 